\title{
Introduction: The Changing Face of Citizen Action
}

\section{Upfront}

\author{
REMKO BERKHOUT \\ AND FIEKE JANSEN
}

\begin{abstract}
Remko Berkhout and Fieke Jansen analyze the historic changes that have happened to citizen action during 2011. They do so through three entry points. First, they reflect on the assumption that we live in unprecedented times and explore the transformative nature of 2011. Second, they analyze the role played by social media and new technologies. Finally, they reflect on civic agency and ask how we can foster a better understanding and 'reading' of power and agency.
\end{abstract}

KEYWORDS Indignados; Occupy Wall Street; Tahrir Square; civic agency; netizens; technology

\section{Introduction}

The year 2011 will go down in history as the year of the citizen. The Arab Spring sent shockwaves throughout the Middle East, inspiring the Indignados in Southern Europe and beyond. Masses took to the streets in India to support Anna Hazare's fight against corruption. A Summer of riots and protests followed: Greece, Israel, London, Chile and Mexico. Occupy Wall Street soon went viral and survived the Winter. Back to the Middle East - Ghadaffi's downfall in Libya, reality checks in Egypt, flaring protests in Syria, in continued defiance of brutal repression. Amidst this turmoil, social media emerged as the new magic bullet, driving a global citizens' revolution. Yet, a closer look reveals a fine line between euphoria and controversy. This issue of Development looks underneath the drastic events of citizen action of 2011 and critically reflects on the changing role of the citizen in global politics.

The inspiration for this issue was drawn from a dialogue held in September 2011, just before the Occupy movement swung into action. Hivos teamed up with the Institute of Social Studies, the Centre for Internet Society and the Institute of Development Studies to bring together a global group of 35 activists, practitioners and academics to reflect on the changing face of citizen action. For two days, participants from 20 countries shared perspectives and analyses on the shifting political landscape, dynamics of mobilization and activism in the twenty-first century. The dialogue asked whether we are witnessing a new wave of social mobilization? If so, how do we make sense of its main drivers and manifestations? What are the implications for development practitioners and their organizations, accused of being out of touch and out of date? What do these dynamics imply for research agendas and methodologies? 
In this introduction, we pick up three themes that stand out in the discussion and contributions to this issue of Development. The first theme unpacks the claim that we are living in unprecedented times and reflects on the transformative nature of 2011. The second theme moves beyond the hype surrounding social media and sheds light on the real concerns around technology in society. It asks, what are the consequences when the public sphere is controlled by complex power structures between government, private sector and individuals on local, national and international level? The third theme is about civic energy and the pulse on the street. Can we foster a better understanding and 'reading' of power and civic agency? How, if at all, can such agency be nurtured or supported?

\section{Unprecedented times?}

The first section of this journal offers a set of lenses through which we can critically analyze the claims that we are living through an unprecedented era of radical civic action and imminent global citizen revolutions. In 'Resisting Revolutions', Nishant Shah separates the wheat of revolution from the chaff of resistance. Resistance is posited as an endemic condition of governmentality that often strengthens rather than unsettles the status quo. A case in point, suggests Shah, is the Anna Hazare campaign, which had all the features of a new radical movement for 'real democracy' in India. Yet in practice the campaign did little else than strengthening the very system it had sought to oppose. Instead, radical or revolutionary expressions of citizen action are closely associated with what Akshay Khanna conceptualizes as 'unruly politics' collective action in search of alternative spaces of political action beyond the established order in deliberate defiance of the local 'rules of the game'. Regardless of the outcomes, Tahrir Square and Occupy Wall Street qualify as acts of revolution because they have generated new spaces and modalities of political action. Unruly politics, as an emerging concept, may help in understanding and appreciating phenomena inviting a new mode of political enquiry, which spills outside of traditional notions of politics, and in which the relevance of acts and events are not reduced to the effect they have on formal structures of the political establishment.

\section{Technology and society}

According to mainstream media, 2011 was also the year of Facebook protest and Twitter revolts, with claims that web 2.0 was fundamental in reshaping the nature of citizen action. Kawa Hassan's report on activists' perceptions of the Arab Spring reveals how such claims are oversimplified. Social media are enabling new forms of organizing and networked forms of mobilization. There is also increased recognition of a global generation of digital natives exercising their political agency in new and important ways. Yet, claims of radically positive effects on democracy have to date proven elusive and the Internet's transformative political potential cannot yet be taken for granted. On the contrary, suggest Sonia Correa and Rebecca MacKinnon, the Internet complicates as much as it facilitates citizen action. The public sphere increasingly depends on technology and the online spaces we inhabit are not politically neutral. They are subject to the same dynamics of inclusion, exclusion and power abuse, around race, sexuality and gender as in the off-line world. Moreover, most digital platforms are governed by the private sector, which further complicates checks and balances in the online world. Argues MacKinnon: 'It is time to stop debating whether the Internet is an effective tool for political expression and to move on to the much more urgent question on how digital technology can be structured, governed, and used to maximize the good it can do in the world and minimize the evil'. What we have is an increasingly complex hybrid public sphere, with fuzzy power constellations in which citizens and netizens have to organize, mobilize and strategize to advance their agenda's. As Correa et al. demonstrate with the case of Internet regulation in Brazil, these challenges demand and invite new coalitions, strategies and connections between off-line and online activists and movements, that have to date not materialized to their full potential. 


\section{Power and agency}

Clearly, existing knowledge frameworks are not yet able to handle the complexities of citizen action in an (inter)connected world. After all, what the drastic expressions of civic action of 2011 had in common is that to academics, policymakers and development practitioners alike, they seemed to come from nowhere. Normative frameworks and analytical perspectives prevented observers from being able to take the pulse of the street, argues Mariz Tadros in a recent IDS bulletin about Egypt's revolt (Tadros, 2012). Tadros points to the blinkered disciplinary silos and methodological tools. She calls for new lenses that would enable academics to better 'see like citizens'. In their contribution, Kees Biekart and Alan Fowler offer Civic Driven Change as one such a lens for societal analysis. Social change is about more than big events and dramatic turning points.

It is also about the energies, ideas and imagination spurring individual and collective actions of people to improve their lives on a day-by-day basis. This vital, quiet, slow and dense fabric of social and political life, whether online or off-line, transcends a 'sectored' view of society and tangible manifestations of civic life. As an emerging analytical and normative framework, Civic Driven Change enables the reframing of old questions as well as the emergence of new questions around citizen agency and social mobilization. How does agency work? What are its drivers? Where is it located, how does it translate into action or deliberate inaction? How are uncivic expressions of agency different from civic manifestations of agency? Why and when are individuals willing to act in the interest of a larger social group?

Building on these questions, Harry Boyte reflects on Occupy Wall Street and the Tea Party. In both, he finds manifestations of civic and uncivic agency. Like Jenny Pearce in her contribution on power, Boyte calls for a democratizing politics of non-dominating power, that "effects a culture shift from me to we'. How could such a shift be fostered? That brings us back to what Sue Soal and Lisa VeneKlassen consider to be the core of citizen action support: nurturing the (personal), empowerment and, most importantly, the shaping of alternatives. In that process, there are no shortcuts. That is why NGOs such as CDRA and Just Associates, against the tide of funding constraints in an age of quick fixes, continue their craft of supporting the slow and intangible dynamics of social movement organizing. There is more than a grain of truth in the assertions that development NGOs are increasingly out of touch with the changing times, ${ }^{1}$ but such criticisms also risk throwing away the baby with the bathwater.

\section{Conclusion with a cause: civic explorations}

In June last year, David Sasaki wrote: 'Just halfway into 2011, the events in 1968, the year that rocked the world, look minor in comparison'. (Sasaki, 2011) The interplay between crises and globalizations of various kinds is fundamentally reshaping global and local politics and citizens are recasting their role in it. Lisa VeneKlassen argues that while many of the underlying dynamics of citizen action remain the same, the face of citizen action is changing. Yet, it is not entirely clear how these changes are working out in terms of impact, effectiveness and transformation. From the ongoing turbulence in Egypt to the edgy work of Anonymous and new viral campaigns like Kony2012, no citizen headline act has been without questions and controversy. And as many of the contributions point out, cynicism and perverse confluences live side by side with the hope and excitement about the energy and imagination of citizens to get by or change their world for the better.

Despite a rich body of research, substantial knowledge gaps around questions of agency, social mobilization and effective citizen action remain. For both researchers and supporters of civic action, the game is only becoming more complex. Existing knowledge frameworks are in need of an update and fresh perspectives from transdisciplinary research. As a follow up to the September dialogue, Hivos is now convening the civic explorations knowledge programme. This programme will bring academics, policymakers, 
practitioners and activists together for real time research and reflection on the evolving nature of citizen action in an interconnected multipolar world. Co-creation will be a key programme principle, and so we invite you to join the conversation at http://www.hivos.net/civicexplorations.

\section{Note}

1 For a recent overview on the discussions about the future of NGOs in a globalizing world, see the Hivos Future Calling initiative, on http://www.hivos.net/futurecalling

\section{References}

Sasaki, David (2011) 'The Youth-Led Revolutions of 1968 and 2011', in Nishant Shah and Fieke Jansen (eds.) Digital alternatives with a cause, book three - To act, Bangalore: Centre for Internet Society also available on www. cis-india.org/digital-natives, p. 17.

Tadros, Mariz (ed.) (2012) 'Special Issue:The Pulse of Egypts Revolt', IDS bulletin 43(1): http://onlinelibrary.wiley.com/ doi/10.1111/idsb.2012.43.issue-1/issuetoc, p. 5, accessed 19 March 2012. 